\title{
IMAGENS DE ALTA RESOLUÇÃO ESPACIAL PARA ANALISAR A INFLUÊNCIA DA COBERTURA ARBÓREA NO MICROCLIMA DAS RUAS DE CURITIBA-PR
}

\author{
Angeline Martini ${ }^{1}$, Mayssa Mascarenhas Grise ${ }^{2}$, Daniela Biondi ${ }^{3}$, \\ Demóstenes Ferreira da Silva Filho ${ }^{4}$
}

\section{RESUMO}

O objetivo desta pesquisa foi analisar a influência da cobertura arbórea no microclima de ruas da cidade de Curitiba-PR por meio de imagens de satélite de alta resolução. Para isso foram selecionadas três ruas arborizadas e três sem cobertura arbórea. Foram instaladas miniestações para coleta de dados de temperatura e umidade relativa, nas quatro estações do ano, com início no inverno de 2011. A determinação da porcentagem de cobertura arbórea foi realizada a partir de técnicas de sensoriamento remoto, na qual foram utilizadas imagens do satélite GeoEye-1. Para a escolha do melhor resultado, testaram-se diferentes dimensões de buffers ao redor dos pontos de coleta: 100, 75, 50, 25, 10 e 5 m. Os resultados indicam que os pontos com maior cobertura arbórea foram os que proporcionaram menores temperaturas e maiores valores de umidade relativa. Por meio da análise de correlação simples e dos diagramas de dispersão, pode-se afirmar que a melhor forma de avaliar a influência da cobertura arbórea no microclima foi com a utilização de buffers com distância de 25 e $50 \mathrm{~m}$. Conclui-se que a utilização de imagens de satélite de alta resolução espacial mostrou-se eficiente na identificação e quantificação da cobertura arbórea da cidade, bem como na determinação da influência da vegetação no microclima urbano.

Palavras-chave: Clima urbano; Arborização urbana; Temperatura; Umidade relativa.

\footnotetext{
Recebido em 24.03.2014 e aceito em 05.05.2015

1 Engenheira Florestal. Doutoranda do Programa de Eng. Florestal da UFPR. Curitiba/PR. Email: martini.angeline@gmail.com

2 Bióloga, Dra. Em Engenharia Florestal pela UFPR. Curitiba/PR. Email: mayssamonteiro@gmail.com

3 Engenheira Florestal, Dra, Professora Associada IV do Departamento de Ciências Florestais, UFPR, Bolsista Produtividade em Pesquisa - CNPq, Curitiba/PR. Email: dbiondi@ufpr.br

4 Agrônomo, Dr., Docente do programa de pós-graduação em Recursos Florestais da Universidade de São Paulo. Piracicaba, SP. E-mail: dfilho@usp.br
} 


\title{
HIGH SPATIAL RESOLUTION IMAGES TO ANALYZE THE INFLUENCE OF TREE COVER ON STREET MICROCLIMATE OF CURITIBA-PR
}

\begin{abstract}
The aim of this paper was to analyze the influence of tree cover on microclimate streets of Curitiba-PR, through high spatial resolution satellite images. Where installed mini-stations to collect data about temperature and relative humidity in six streets, three with trees and three without trees. Where collected data in the four seasons, starting in 2011 winter's. Images from satellite GeoEye-1 were used to percentage determination of tree cover by remote sensing techniques. To select the most appropriate, was tested different buffers sizes around the points: $100,75,50,25,10$ and $5 \mathrm{~m}$. The results indicate that the points with greater tree cover indicates lower temperatures and higher relative humidity. The simple correlation and scatter plots analysis showed that buffers with $25 \mathrm{~m}$ and $50 \mathrm{~m}$ where the more appropriate to measure the influence of tree cover on microclimate. Was concluded that the high spatial resolution satellite images was useful in identifying and quantifying city's tree cover.
\end{abstract}

Keywords: Urban climate; Urban forest; Temperature; Relative Humidity.

\section{INTRODUÇÃO}

O aumento populacional das zonas urbanas, aliado à falta de planejamento adequado, têm provocado inúmeros problemas, principalmente no contexto social e ambiental (MARTINI, 2013). Dentre os quais, as alterações climáticas são talvez os mais significativos impactos.

As mudanças climáticas observadas ocorrem porque as cidades apresentam estruturas e elementos que substituem os elementos naturais, como: asfalto, edificações, pisos de concreto, telhas de cerâmica, amianto, vidros e estruturas metálicas (SILVA FILHO et al., 2005). Segundo os mesmos autores, estes elementos, com elevada capacidade refletora, condicionam um microclima seco e quente, ampliando o desconforto da população pela alteração do balanço de energia. Além de aumentar a predisposição para inundações e proporcionar compactação e impermeabilização do solo. Assim, é possível perceber que as 
áreas densamente construídas apresentam temperaturas mais elevadas quando comparadas ao seu entorno, criando "ilhas de calor urbano" (LEAL, 2012).

Muitas pesquisas apontam o uso da vegetação como fator amenizador dos problemas climáticos ocorrentes nas cidades. Leal (2012) afirma que o planejamento das florestas urbanas, contemplando a criação de parques, bosques e arborização de ruas, são as medidas mais eficientes para promover mudanças, principalmente no microclima urbano. Pois, quando a vegetação é bem distribuída, o balanço de energia de toda a cidade pode ser modificado pela adição de mais superfícies evaporativas, mais radiação absorvida pode ser dissipada na forma de calor latente e a temperatura urbana pode ser reduzida (YU; HIEN, 2006).

Segundo Lombardo et al. (2012), as áreas verdes urbanas, são componentes estratégico da cidade, pois contribuem com o ciclo hidrológico, controle de erosões, estabilização de encostas, regulação dos fluxos em canais de drenagem, oferecem áreas de sombreamento, retenção de partículas, redução do ruído além de contribuir para a democratização de espaços para práticas de lazer, atividades de educação ambiental e amenização térmica.

Conforme Silva (2009), a influência da vegetação se manifesta nas mais variadas escalas climáticas, porém para a configuração urbana de um lugar, o clima urbano tem na escala microclimática, seu principal grau de interferência. A microescala é escala típica dos microclimas urbanos, pode ser definida pelas características dos elementos individuais como construções, árvores, estradas, ruas, pátios e jardins, podendo variar numa escala de menos de um a centenas de metros. Portanto, a presença da vegetação nas áreas urbanas cria um microclima que difere daquele das áreas sem vegetação (LIMA, 2009).

Muitas questões sobre a vegetação urbana podem ser tratadas rapidamente e de forma eficaz usando métodos e ferramentas geoespaciais (GRISE et al., 2013). O uso de imagens de satélite para estudos de vegetação no ambiente urbano é uma prática utilizada principalmente quando se trata de cidades de grande porte (VELASCO el al., 2007). Segundo os mesmos autores estas imagens permitem uma visão do todo, possibilitando a obtenção de informações que seriam inviáveis de serem adquiridas sem a utilização das mesmas.

As imagens de satélite contribuem para identificar as áreas mais degradadas da paisagem urbana, porque apresentam uma configuração diferenciada de acordo com o dinamismo da ocupação e uso do solo (LOMBARDO et al., 2012). Assim, em pouco tempo e em larga escala são obtidos dados espaciais a partir dos quais os atributos da vegetação 
urbana podem ser identificados (WARD, 2007), espacializados e analisados nos mais diversos aspectos.

Ferramentas geoespaciais como o Sensoriamento Remoto (SR) e o Sistema de Informação Geográfica (SIG) podem fornecer, em pouco tempo e de maneira extensa, dados espaciais a partir dos quais a arborização urbana pode ser identificada, quantificada, qualificada e analisada quanto a sua distribuição espacial na cidade. As imagens de satélite de alta resolução espacial, tem se mostrado eficientes na extração de informações da cena, atingindo um alto nível de detalhamento (FERNANDES, 2005), sendo usadas na identificação e mapeamento das árvores e florestas urbanas (PU; LANDRY, 2012).

Tendo em vista que a utilização de imagens de satélite de alta resolução para classificação da vegetação urbana tem se mostrado eficiente e que as alterações do clima nas cidades têm recebido maior atenção por parte dos planejadores, o objetivo desta pesquisa foi analisar a influência da cobertura arbórea no microclima de ruas da cidade de Curitiba-PR por meio da utilização de imagens de satélite de alta resolução.

\section{MATERIAIS E MÉTODOS}

A pesquisa foi realizada na cidade de Curitiba, localizada no Primeiro Planalto Paranaense, a 934,6 m de altitude média. O marco zero da cidade situa-se na Praça Tiradentes, na latitude 25 25' 40" S e longitude 49 16' 23" W. De acordo com a classificação climática de Köppen, o clima é do tipo Cfb - subtropical úmido, mesotérmico, sem estação seca, com verões frescos e invernos com geadas frequentes (INSTITUTO DE PESQUISA E PLANEJAMENTO URBANO DE CURITIBA - IPPUC, 2011).

O clima de Curitiba apresenta verão ameno e o inverno moderado com alguns dias mais rigorosos. As temperaturas médias são de $19,7^{\circ} \mathrm{C}$ no verão e $13,4^{\circ} \mathrm{C}$ no inverno. A precipitação de chuvas apresenta média anual de 1.419,91 mm com um período de estiagem, não fixo, entre o outono e o inverno (IPPUC, 2011).

Para a realização deste trabalho foram selecionadas seis ruas da cidade, três arborizadas e três sem cobertura arbórea. Nestas ruas foram instaladas miniestações da marca Kestrel ${ }^{\circledR}$, permanecendo fixados em um tripé, com a mesa de sensores a 1,50 m de altura. Devido à disponibilidade de equipamentos as coletas foram realizadas em dias diferentes, aos pares, em cada dia um aparelho permaneceu em uma rua arborizada e outro em uma rua sem cobertura arbórea. 
As ruas selecionadas foram: Fernando Amaro (P1, arborizada) e Marechal Deodoro (P2); Dr. Goulin (P3, arborizada) e Augusto Stresser (P4); e Estados Unidos, sendo um trecho arborizado (P5) e outro não (P6) (Figura 1). Os equipamentos foram posicionados na porção central da quadra, na calçada sul das ruas de sentido leste-oeste (Mal. Deodoro, Fernando Amaro, Augusto Stresser e Dr. Goulin) e na calçada oeste da rua de sentido norte-sul (Estados Unidos), de maneira a reduzir a interferência causada pela movimentação aparente do sol. Por questões de segurança e outras possíveis interferências humanas, a coleta das variáveis meteorológicas foi realizada por meio de campanhas de monitoramento, na qual uma equipe de pesquisadores permaneceu junto aos aparelhos durante todo o período de coleta.

Figura 1. Localização das amostras (pontos) na cidade de Curitiba, na imagem digital do satélite GeoEye-1 (janeiro/2009)

Figure 1. Location of the study samples in Curitiba-PR, in digital image GeoEye-1 satellite (january/ 2009)

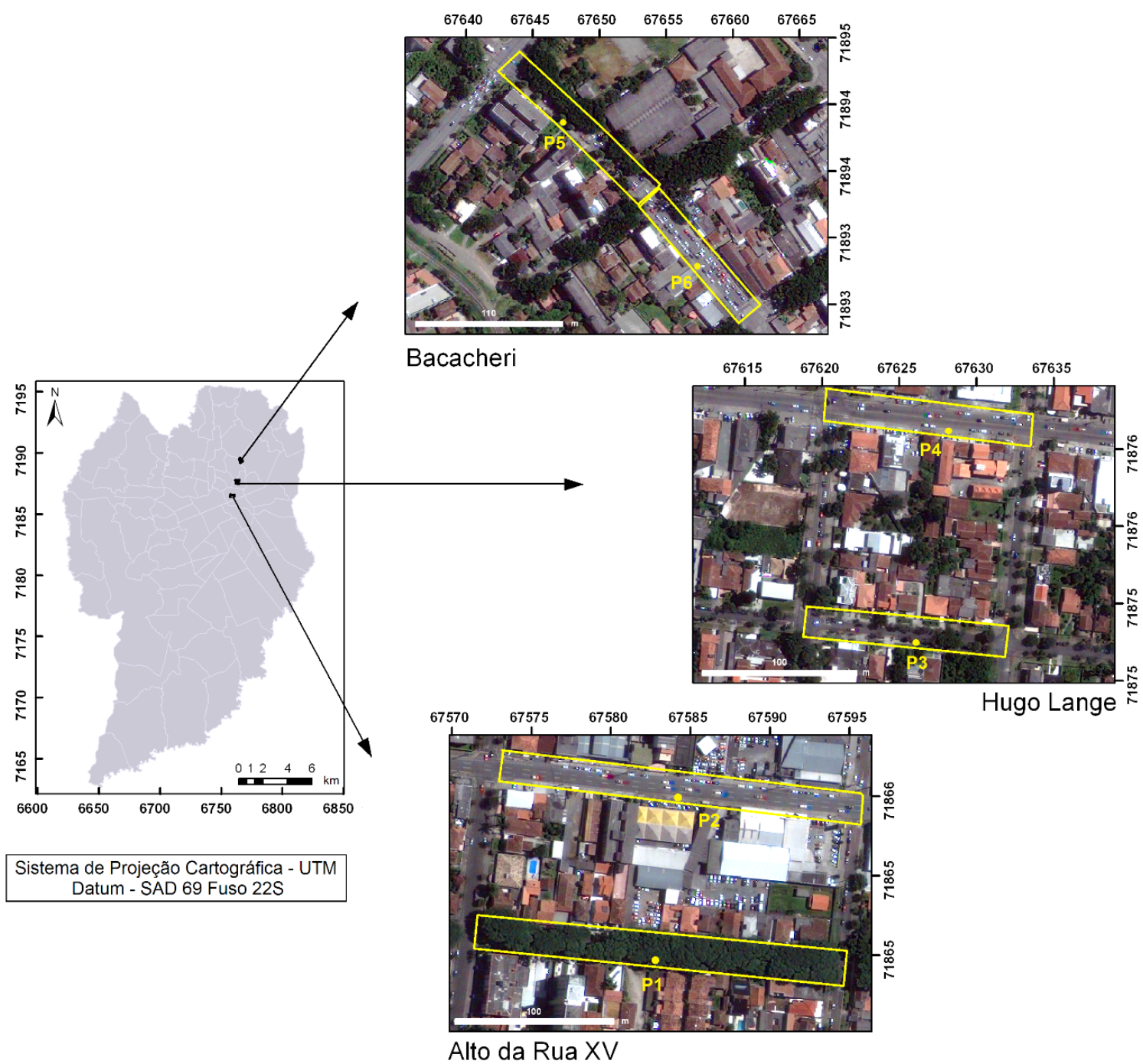


As variáveis meteorológicas utilizadas nesta pesquisa foram temperatura do $\operatorname{ar}\left({ }^{\circ} \mathrm{C}\right)$ e umidade relativa (\%). As coletas foram realizadas nas quatro estações do ano, no inverno e primavera de 2011 e no verão e outono de 2012, como forma de repetição. O período de coleta dos dados foi das 9 às 15 horas (horário de Brasília), sendo corrigido para 10 e 16 horas no horário de verão, com intervalo de monitoramento de 1 minuto, o que gerou um conjunto de 360 dados por dia, em cada rua.

As médias de temperatura e umidade relativa foram determinadas para cada ponto. No entanto, a comparação entre os seis pontos juntos não foi possível, uma vez que foram coletados em dias diferentes. A análise estatística aplicada (SNK 95\%) aos dados oficiais obtidos pelo Instituto Nacional de Meteorologia (INMET) confirmaram que tratam-se de dias estatisticamente diferentes. Assim, adotou-se como base as informações meteorológicas fornecidas pelo INMET, nos dias e horários correspondentes ao período de coleta em campo. As médias dos valores de temperatura e umidade relativa oficiais do INMET foram subtraídos dos valores coletados em campo, em seus respectivos dias. Desta forma, a diferença de temperatura e umidade relativa gerada em cada ponto foi comparada com a área de cobertura arbórea existente no seu entorno, para verificar a influência que esta exerce no microclima.

A determinação da cobertura arbórea foi realizada a partir de técnicas de sensoriamento remoto, onde foram utilizadas imagens digitais de alta resolução espacial, do Satélite GeoEye-1, adquiridas comercialmente da empresa Engesat. As imagens apresentam bandas do visível e infravermelho próximo, já interpoladas pelo método da Convolução Cúbica, georreferenciadas e datadas de janeiro de 2009.

A imagem foi classificada no software MultiSpec, composta nas cores fundamentais "RGB" correspondendo às bandas 4, 3, 2 respectivamente. Para a classificação automática supervisionada, utilizou-se 0 algoritmo ECHO (Extraction and Classification of Homogeneous Objects). As classes estabelecidas de uso e ocupação do solo da área estudada foram: relvado, cobertura arbórea, asfalto, telha cerâmica, telha clara, telha escura, piso claro, sombra, nuvem e piscina. A validação da exatidão do mapeamento temático foi realizada por meio da estatística Kappa, que a partir da construção de uma matriz de erro torna possível utilizar de técnicas de análise multivariada para determinar a concordância entre a verdade terrestre e o mapa temático.

A imagem classificada foi processada no software Quantum GIS 1.8. Este processamento consistiu na criação de buffers ao redor dos pontos de coleta dos dados meteorológicos. Foram criados buffers com as seguintes dimensões: 100 m, 75 m, 50 m, 25 $\mathrm{m}, 10 \mathrm{~m}$ e $5 \mathrm{~m}$. A determinação da área de uso e ocupação do solo dos pontos de coleta 
dos dados meteorológicos para cada tamanho de buffer foi estabelecida no software MultiSpec. Os valores dos dados meteorológicos e área de cobertura arbórea foram comparados por meio da análise de correlação simples e do diagrama de dispersão.

\section{RESULTADOS E DISCUSSÃO}

A classificação da imagem realizada permite quantificar a área de cada classe de uso e ocupação do solo (Figura 2).

Figura 2. Classificação da imagem GeoEye com abrangência dos pontos selecionados

Figure 2. Rating GeoEye image with coverage of selected points

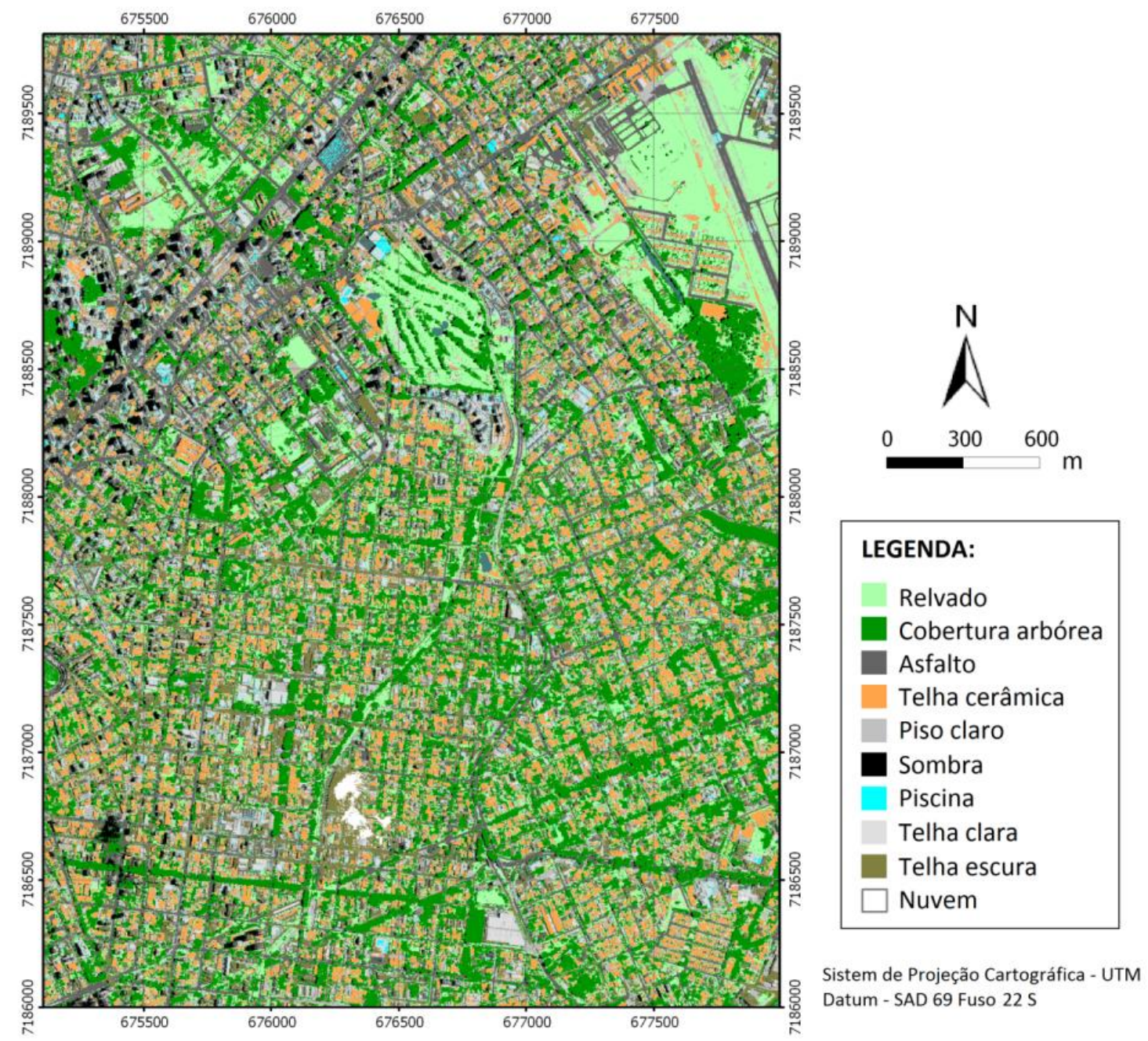

Com base na Figura 1 é possível observar que a classe mais expressiva na imagem foi a cobertura arbórea (22,2\%). Resultado semelhante ao encontrado pela Prefeitura de Curitiba, que também utilizou técnicas de sensoriamento remoto em imagens 
GeoEye. Na pesquisa realizada pela prefeitura, verificou-se que as áreas de cobertura vegetal da cidade atingem $26 \%$ do território (CURITIBA, 2013).

O alto valor de cobertura arbórea existente é um dos motivos que faz a cidade ser conhecida como a "Capital Ecológica" e símbolo nos instrumentos de política que visam a conservação da natureza em áreas urbanas.

Deve-se ressaltar, que na presente pesquisa a exatidão geral da classificação aplicada a imagem GeoEye foi de $95,7 \%$ e o índice Kappa encontrado, 93,8\%. Valores satisfatórios para ambos testes. A partir da classificação realizada foi possível criar diferentes dimensões de buffers e visualizar a cobertura arbórea existente em cada uma delas (Figura 3).

Figura 3. Porcentagem de cobertura arbórea em cada ponto e dimensões de buffer Figure 3. Percentage of tree cover at each point and dimensions of buffer

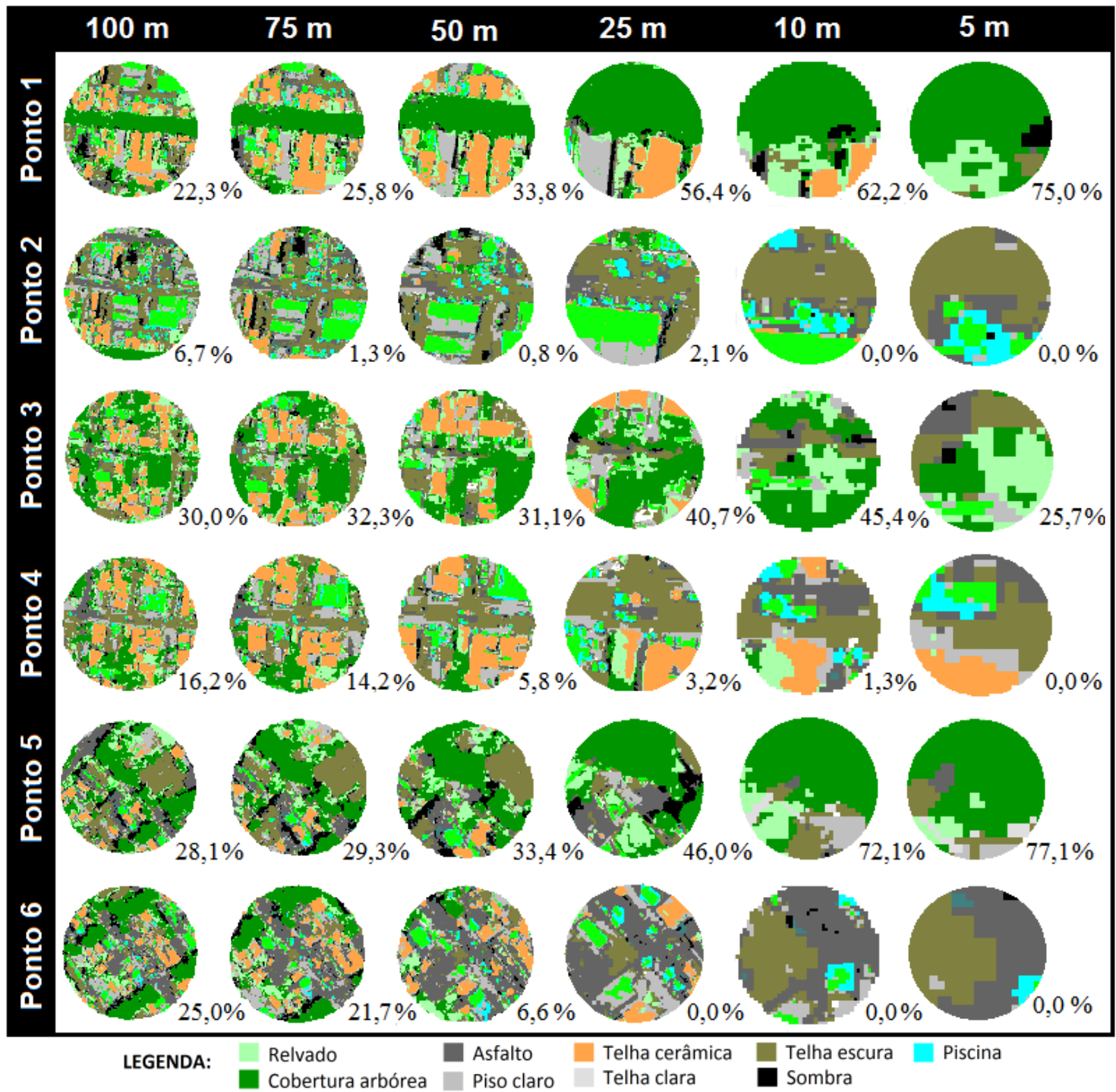


De maneira geral, pode-se observar na Figura 2 que em todos os buffers criados, os pontos 1, 3 e 5 apresentam maiores proporção de cobertura arbórea do que os pontos 2, 4 e 6 . Diferenças mais significativa podem ser observadas nos buffers de 5, 10 e 25 metros.

Os valores médios de temperatura e umidade relativa, utilizados para analisar a influência da cobertura arbórea referentes à diferença entre os dados coletados em campo e os registrados pelo INMET, são apresentados na Tabela 1.

Tabela 1. Média dos valores meteorológicos utilizados para analisar a influência da cobertura arbórea, referente à diferença (Dif.) entre os dados coletados em campo (Col.) e os registrados pelo INMET (Ofc.)

Table 1. Average meteorological data used to analyze the influence of tree cover, of the difference (Dif.) between the data collected in the field (Col.) and registered by INMET (Ofc.)

\begin{tabular}{|c|c|c|c|c|c|c|c|c|c|c|c|c|c|}
\hline & \multicolumn{3}{|c|}{ Inverno } & \multicolumn{3}{|c|}{ Primavera } & \multicolumn{3}{|c|}{ Verão } & \multicolumn{3}{|c|}{ Outono } & \multirow{2}{*}{$\begin{array}{c}\text { Média } \\
\text { da } \\
\text { Dif. }\end{array}$} \\
\hline & 1 & fo & & & & & & & & & & & \\
\hline \multicolumn{14}{|c|}{ Temperatura $\left({ }^{\circ} \mathrm{C}\right)$} \\
\hline Ponto 1 & 9,7 & 7,7 & 2,0 & 16,2 & 15,7 & 0,5 & 25,0 & 24,5 & 0,5 & 17,7 & 16,9 & 0,8 & 0,9 \\
\hline Ponto 2 & 10,1 & 7,7 & 2,4 & 18,5 & 15,7 & 2,8 & 28,7 & 24,5 & 4,2 & 19,8 & 16,9 & 2,9 & 3,1 \\
\hline Ponto 3 & 13,8 & 9,5 & 4,3 & 21,7 & 18,8 & 2,9 & 28,7 & 24,6 & 4,1 & 21,5 & 20,7 & 0,8 & 3,0 \\
\hline Ponto 4 & 13,8 & 9,5 & 4,3 & 21,5 & 18,8 & 2,7 & 30,5 & 24,6 & 5,9 & 23,8 & 20,7 & 3,1 & 4,0 \\
\hline Ponto 5 & 13,0 & 12,9 & 0,2 & 16,3 & 15,8 & 0,5 & 28,3 & 28,0 & 0,28 & 18,5 & 17,5 & 1,0 & 0,5 \\
\hline Ponto 6 & 16,3 & 12,9 & 3,5 & 18,6 & 15,8 & 2,8 & 30,3 & 28,0 & 2,35 & 18,7 & 17,5 & 1,3 & 2,5 \\
\hline \multicolumn{14}{|c|}{ Umidade Relativa (\%) } \\
\hline Po & 5,4 & 0,5 & 5,1 & 4,3 & 63,7 & $-0,6$ & 46,2 & 51,0 & 4,5 & 73,7 & 80,6 & 6,9 & 4,0 \\
\hline Ponto 2 & 61,2 & 70,5 & 9,3 & 53,8 & 63,7 & 9,9 & 38,7 & 51,0 & 12,0 & 68,7 & 80,6 & 11,9 & 10,8 \\
\hline Ponto 3 & 34,5 & 41,2 & 6,7 & 46,1 & 54,5 & 8,4 & 40,1 & 48,6 & 8,5 & 61,9 & 61,4 & $-0,5$ & 5,8 \\
\hline Ponto 4 & 33,4 & 41,2 & 7,8 & 46,9 & 54,5 & 7,6 & 34,7 & 48,6 & 13,9 & 52,2 & 61,4 & 9,2 & 9,6 \\
\hline Ponto 5 & 64,5 & 61,3 & $-3,2$ & 61,1 & 60,6 & $-0,5$ & 46,3 & 47,9 & 1,6 & 77,6 & 81,8 & 4,2 & 0,5 \\
\hline Ponto 6 & 53,1 & 61,3 & 8,2 & 51,7 & 60,6 & 8,9 & 42,2 & 47,9 & 5,7 & 74,2 & 81,8 & 7,6 & 7,6 \\
\hline
\end{tabular}

Observa-se na Tabela 1 o cálculo da média das diferenças encontradas provenientes das quatro estações do ano, estes valores foram os dados meteorológicos utilizados para a comparação com a cobertura arbórea. Com relação à temperatura pode-se notar que os dados oficiais foram inferiores aos coletados em todos os pontos e estações do ano. Isto ocorre porque a medição oficial é realizada em uma área aberta, com gramado e com o entorno pouco urbanizado. Com a análise desta tabela, pode-se inferir que o ponto 4 é o ambiente que proporciona maiores valores de temperatura, uma vez que apresentou a maior diferença de temperatura $\left(4^{\circ} \mathrm{C}\right)$ quando comparado com os dados oficiais. Por outro lado, o ponto 5 foi o que apresentou a menor diferença média $\left(0,5^{\circ} \mathrm{C}\right)$ em todas as estações do ano. 
A umidade relativa pode ser analisada desta mesma maneira. Uma vez que os dados oficiais de umidade relativa, em sua maioria, foram maiores do que os coletados nos diferentes pontos. Assim, pode-se afirmar que o ponto 2 foi o que apresentou os menores valores de umidade relativa, pois foi a maior diferença encontrada quando se compara com os dados oficiais. Já o ponto 5 foi o que apresentou os maiores valores de umidade relativa, apresentando a menor diferença $(0,5 \%)$.

Ao comparar a Figura 3 com a Tabela 1 é possível observar que os pontos com maior cobertura arbórea (1 e 5) foram os que proporcionaram menores temperaturas (menor diferença média) e maiores valores de umidade relativa (menor diferença média), do que os demais. Esta afirmação pode ser melhor observada, quando se analisa o buffer de $5 \mathrm{~m}$, onde os pontos que apresentam cobertura arbórea inferior a $30 \%(2,3,4$ e 6) tiveram a menor diferença média de temperatura e umidade relativa.

Estes resultados confirmam o benefício gerado pela cobertura arbórea no microclima urbano. Segundo Mahmoud (2011) esse efeito é devido à redução da passagem dos raios solares para o chão, proporcionando sombreamento a essa área. Hernandes et al. (2002) explica que o dossel das copas das árvores proporciona uma barreira que impede a penetração da maior parte da radiação solar durante o dia, o que implica menor aquecimento do solo, menor emissão de radiação de ondas longas e menor aquecimento do ar no espaço entre o solo e as copas das árvores. Além disso, Abreu (2008) ressalta que a evapotranspiração das plantas é que exerce efeito muito positivo no clima urbano, pois esse processo tem a capacidade de absorver calor, o que leva à diminuição da temperatura do microclima local nas horas de maior calor, além de fornecer vapor d'água à atmosfera.

A análise de correlação simples aplicada entre os valores médios de diferenças das variáveis meteorológicas e a porcentagem de cobertura arbórea existente em cada buffer criado revelou resultados significativos (Tabela 2).

Tabela 2. Análise de correlação simples aplicada a cada buffer e variável meteorológica Table 2. Simple correlation analysis applied to each buffer and meteorological variable

\begin{tabular}{ccccccc} 
Variáveis & $\mathbf{1 0 0} \mathbf{~}$ & $\mathbf{7 5} \mathbf{~ m}$ & $\mathbf{5 0} \mathbf{~ m}$ & $\mathbf{2 5} \mathbf{~ m}$ & $\mathbf{1 0} \mathbf{~ m}$ & $\mathbf{5} \mathbf{~ m}$ \\
\hline Temperatura & $-0,46$ & $-0,52$ & $-0,71$ & $-0,74$ & $-0,56$ & $-0,48$ \\
Umidade Relativa & 0,76 & 0,81 & 0,90 & 0,85 & 0,65 & 0,40 \\
\hline
\end{tabular}

Observa-se na Tabela 2 que a variável temperatura apresentou forte correlação (> 0,70) com o buffer de 25 e $50 \mathrm{~m}$, para os demais pontos a correlação foi moderada. Já a umidade relativa apresentou forte correlação com os buffers de 50, 25, 75 e 100 m. Assim, 
por meio da análise de correlação simples, pode-se afirmar que a melhor forma de avaliar a influência da cobertura arbórea no microclima foi a criação de buffers com distância radial de 25 e $50 \mathrm{~m}$.

Quando se compara os dados meteorológicos e a área de cobertura arbórea por meio do diagrama de dispersão, tem-se resultados semelhantes, porém com valores de baixa intensidade (Figura 4).

Figura 4. Diagrama de dispersão para cada buffer e variável meteorológica

Figure 4. Scattergram for each buffer and meteorological variable

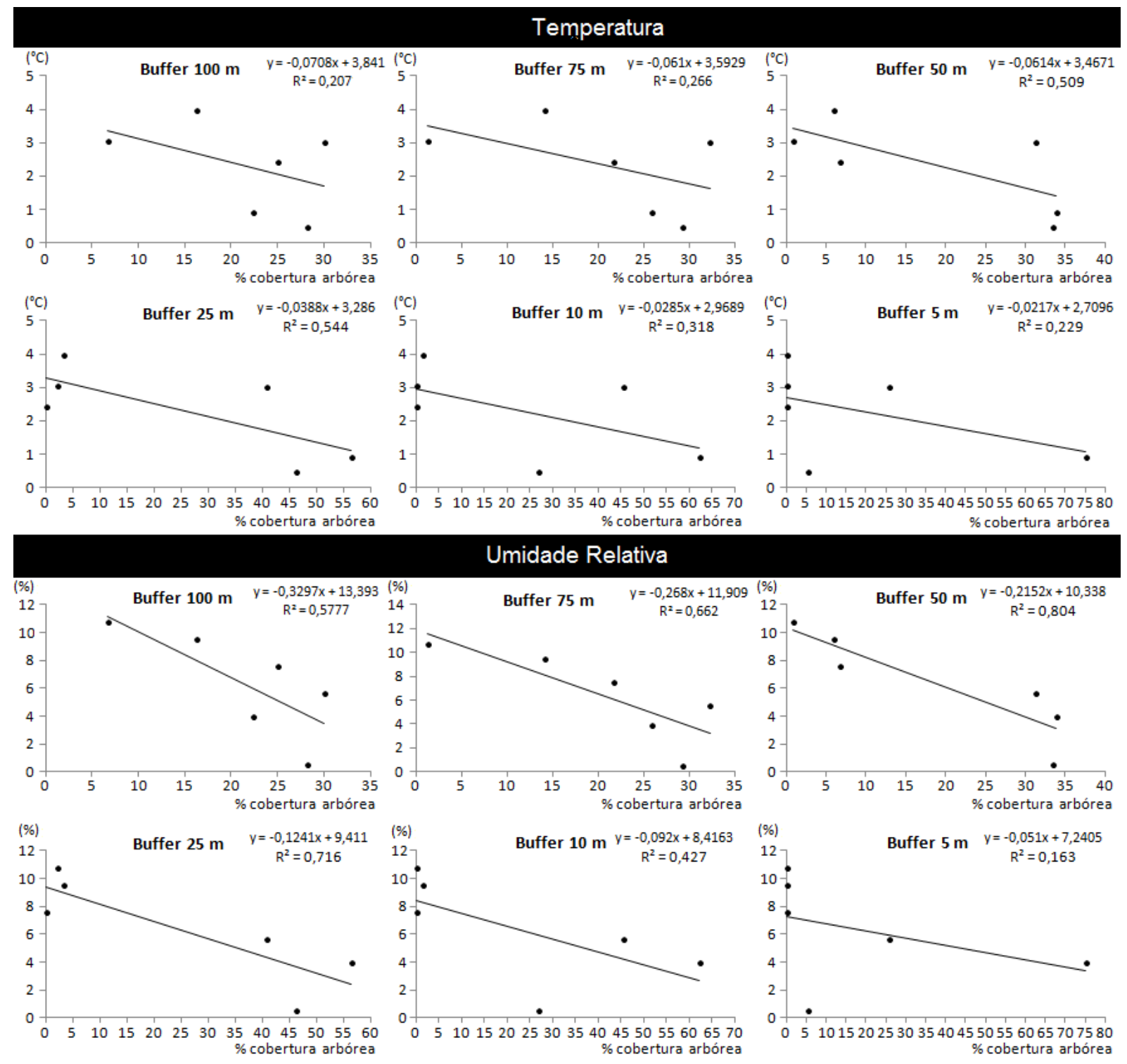

Pode-se observar por meio dos diagramas de dispersão que para a variável temperatura o maior coeficiente de determinação foi encontrado para o buffer de $25 \mathrm{~m}\left(\mathrm{R}^{2}=\right.$ 
0,54) e $50 \mathrm{~m}\left(\mathrm{R}^{2}=0,51\right)$. Para a variável umidade relativa, o maior coeficiente de determinação foi encontrado para o buffer $50\left(R^{2}=0,80\right)$ e $25 m\left(R^{2}=0,72\right)$. Desta forma, pode-se afirmar que para esta pesquisa que analisa a influência da cobertura arbórea no microclima urbano, por meio de técnicas de sensoriamento remoto, a utilização de buffers com distâncias de 25 e 50 m são os que demonstraram resultados significativos.

\section{CONCLUSÃO}

A utilização de imagens de satélite de alta resolução espacial se mostrou eficiente na identificação e quantificação da cobertura arbórea da cidade de Curitiba.

Com relação à influência da cobertura arbórea no microclima, pode-se afirmar que as áreas com maiores proporções de cobertura arbórea foram as que apresentaram menores valores de temperatura e maiores valores de umidade relativa em todas as estações do ano.

A influência da cobertura arbórea no microclima pôde ser notada visualmente, quando se analisou a imagem de todos os buffers criados ao redor do ponto de interesse e os valores meteorológicos utilizados. No entanto, estatisticamente verificou-se que só os buffers com distâncias de 25 e $50 \mathrm{~m}$ foram os que apresentaram maiores correlações com os dados meteorológicos.

\section{AGRADECIMENTOS}

À Fundação Araucária de Apoio ao Desenvolvimento Científico e Tecnológico do Paraná pelo financiamento à compra dos equipamentos.

\section{REFERÊNCIAS}

ABREU, L. V. de. Avaliação da escala de influência da vegetação no microclima por diferentes espécies arbóreas. 154f. Dissertação (Mestrado em Engenharia Civil) Faculdade de Engenharia Civil, Universidade Estadual de Campinas, Campinas, 2008.

CURITIBA. Meio Ambiente: Índice de área verde passa para $64,5 \mathrm{~m}^{2}$ por habitante. Disponível em: <http://www.curitiba.pr.gov.br/noticias/indice-de-area-verde-passa-para-645m2-por-habitante/25525> Acesso em: 13/09/2013. 
FERNANDES, S. C. Avaliação de imagens de satélite de alta e muito alta resolução espacial para a discriminação de classes de uso e ocupação do solo : aplicação ao caso da sub-bacia do córrego Capão Comprido no Distrito Federal. 2005. 106p. (Mestrado em Engenharia Civil e Ambiental) - Universidade de Brasília, Brasília, 2005.

GRISE, M. M; ARAKI, H.; BIONDI, D. O uso de imagens de satélite de alta resolução espacial - GeoEye na identificação da arborização urbana. In: Simpósio Brasileiro de Sensoriamento Remoto, 16., 2013, Foz do Iguaçu. Anais... São José dos Campos: INPE, 2013. p. 1030-1037.

HERNANDES, J. L.; PEDRO-JUNIOR, M. J.; BARDIN, L. Diferenças estacionais entre variáveis microclimáticas para ambientes de interior de mata, vinhedo e posto meteorológico em Jundiaí (SP). Bragantia, Campinas, v. 61, n. 2, p. 169-180, 2002.

INSTITUTO DE PESQUISA E PLANEJAMENTO URBANO DE CURITIBA (IPPUC). Desenvolvimento sustentável: Indicadores de sustentabilidade de Curitiba - 2010. Curitiba: IPPUC, 2011. 77p.

LEAL, L. A influência da vegetação no clima urbano da cidade de Curitiba - PR. $172 f$. Tese (Doutorado em Engenharia Florestal) - Universidade Federal do Paraná, Curitiba, 2012.

LIMA, D. C. R.. Monitoramento e desempenho da vegetação no conforto térmico em espaços livres urbanos: o caso das praças de Maringá/PR. 170f. Dissertação (Mestrado em Engenharia Urbana) - Departamento de Engenharia Civil, Universidade Estadual de Maringá, Maringá, 2009.

LOMBARDO, M. A.; SILVA FILHO, D. F; FRUEHAUF, A. L.; PAVAN, D. C. O uso de geotecnologias na análise de da ilha de calor, índice de vegetação e uso da terra. Revista Geonorte, Edição Especial 2, v.2, n.5, p.520-529 , 2012.

MAHMOUD, A. H. A. Analysis of the microclimatic and human comfort conditions in an urban park in hot and arid regions. Building and Environment, v. 46, p. 2641-2656, 2011.

MARTINI, A. Microclima e conforto térmico proporcionado pelas árvores de rua na cidade de Curitiba-PR. 129p. Dissertação (Mestrado em Engenharia Florestal) Universidade Federal do Paraná, Curitiba, 2013.

PU, R.; LANDRY, S. A comparative analysis of high spatial resolution IKONOS and WorldView-2 imagery for mapping urban tree species. Remote Sensing of Environment. v. 124, p. 516-533, 2012. 
SILVA FILHO, D.F. da; PIVETTA, K. F. L.; COUTO, H. T. Z. do; POLIZEL, J. L. Indicadores de floresta urbana a partir de imagens aéreas multiespectrais de alta resolução. Scientia Forestalis, n. 67, p.88-100, 2005.

SILVA, C. F. Caminhos Bioclimáticos: desempenho ambiental de vias públicas na cidade de Terezina - PI. 140f. Dissertação (Mestrado em Arquitetura e Urbanismo) Faculdade de Arquitetura e Urbanismo, Universidade de Brasília, Brasília, 2009.

VELASCO, G. D. N. Potencial da arborização viária na redução do consumo de energia elétrica: definição de três áreas na cidade de São Paulo - SP, aplicação de questionários, levantamento de fatores ambientais e estimativa de Graus-Hora de calor. 123f. Tese (Doutorado em Agronomia) - Escola Superior de Agricultura Luiz de Queiroz, Universidade de São Paulo, Piracicaba, 2007.

WARD, K. T.; JOHNSON, G. R. Geospatial methods provide timely and comprehensive urban forest information. Urban Forestry \& Urban Greening, v. 6, p. 15-22, 2007.

YU, C.; HIEN, W. N. Thermal benefits of city parks. Energy and Buildings, Lausanne, v. 38, p. 105-120, 2006. 